\title{
Administrative Legitimacy and the Democratic Deficit of the European Union
}

Zuzana Murdoch, Sara Connolly and Hussein Kassim

\begin{abstract}
This article suggests a new concept of measurement for the EU's oft-alleged democratic deficit based on two contributions. First, we turn attention to the administrative staff involved in policy-making rather than the (un)accountability of EUs' parliamentarians and executive agents. Second, building on the idea that policy-makers' legitimacy depends on the extent to which they can claim to represent some groups or social interests, we assess the extent to which Commission officials' preferences reflect European citizens' policy stance. Our results indicate a statistically significant positive correlation between the policy preferences of EU administrative staff and their home country population, which, we argue, can provide EU administrators a basic degree of legitimacy relative to their home country.
\end{abstract}

KEY WORDS: Accountability, Democratic deficit, Legitimacy, Representative bureaucracy.

Word Count: 8000 words (7406 words in main text +1.25 table-pages) 


\section{INTRODUCTION}

In what has become a voluminous literature, numerous scholars have examined and debated the EU's democratic credentials (Majone 1994, 1998; Moravcsik 2002, 2004; Scharpf 2009; Kohler-Koch 2010; Wille 2010; Schmidt 2013). While the EU's claim to output legitimacy appears to be broadly accepted, its claim to input legitimacy is still contested. ${ }^{1}$ This paper challenges the latter perspective, and contends that any abandonment of the input side would be premature. The reason is that discussions of the democratic deficit on the input side have tended to focus on electoral accountability. While electoral accountability is an indispensable component, it should not be the only criterion. Rather, as commentators on inclusion and democracy at the national level as well as contributors to the representative bureaucracy literature have argued, democracy also encompasses the composition of the permanent administration. This paper maintains that this argument likewise holds for the European Commission and the EU.

Departing from the emphasis on bureaucrats' demographic background in traditional discussions of representativeness (Kassim et al. 2013: Ch. 2), this paper shifts focus from public officials looking like their principals to thinking like their principals. The central idea is that civil servants thinking like their wider community provides another way to achieve a 'government of the people' (i.e. input legitimacy). This is important as responsiveness to public preferences is one of the key requisites of democratic governance (O'Toole 1997; Rothstein 2009). Using two original datasets collected by the authors, we find a significant match between the beliefs and policy preferences of member state nationals in the Commission and their compatriots at home. As such, even though these constituencies did not elect them, the Commission exhibits some degree of administrative legitimacy - an incarnation of what Lindseth (2010: 14) calls a 'national legitimating mechanism' for the normative and political powers exercised by the EU. By extending the representative 
bureaucracy perspective to the EU and insisting on the inclusion of administrative legitimacy, the paper makes a new contribution to the scholarship on the EU's democratic credentials. By introducing a new metric for the measurement of representativeness, which goes beyond the ascriptive characteristics of bureaucrats, it also contributes to the literature on representative bureaucracy.

\section{The state of the literature and beyond}

Following decades of debate, a consensus emerged that the EU's claim to democratic credentials must rely on the output side (Scharpf 2006) -- that is, on the EU's ability as a collective enterprise to provide benefits to citizens that states can no longer deliver individually. Any claims on the input side are necessarily limited (Follesdal and Hix 2006). In our view, however, such a conclusion appears to be premature. Many of the diagnoses of the EU's democratic deficit on the input side have centred on the role of unelected executive agents (e.g., European Commissioners) and indirectly elected EU parliamentarians in EU policy-making. This limited electoral accountability of EU's political leaders, so the argument goes, undermines the legitimacy of decision-making at the European level and leaves the EU open to adopt 'policies that are not supported by a majority of citizens in many or even most Member States' (Follesdal and Hix 2006: 537).

The strong emphasis on electoral accountability reflects the intimate relation that is presumed to exist between democratic electoral representation and the legitimacy of policymaking (Scharpf 2006; Rothstein 2009; Kröger and Friedrich 2013; Piattoni 2013; Saward 2014). Yet, while electoral representation remains a core aspect of legitimate governance, recent scholarship asserts that 'contemporary democracies are evolving in ways that increasingly undermine the adequacy of these standard accounts' (Kröger and Friedrich 2013: 
156; Curtin et al. 2010; Montanaro 2012; Olsen 2013). A narrow focus on electoral accountability thus is likely to be both restrictive and deficient.

Starting from the observation that policy advice, development, interpretation, implementation and enforcement in the EU involves public officials from all member states, this article explores a new mechanism to improve accountability. Under the standard view of democratic legitimacy and electoral accountability, public administrations lack legitimacy almost by definition as 'most issues and premises that guide administrative behaviour never reach the attention of elected politicians and citizens' (Olsen 2013: 465; Peters 2010). Indeed, EU bureaucrats have only featured in the debate on the EU's democratic deficit to the extent that they are considered to embody the remoteness of EU institutions or the power exercised by 'unelected bureaucrats'.

This paper, by contrast, is inspired by Waldo's (1952: 81) contention that 'a theory of democracy in the twentieth century must embrace administration'. The substantial public administration involved in EU policy-making processes is important for our overall assessment of the EU's input legitimacy. The reason is that the considerable influence of the EU public administration over policy outcomes through the exploitation of bureaucratic discretion (Pollack 2003; Jabko 2006; Olsen 2006; Schafer 2014) creates a framework where popular policy preferences may influence EU policies even if the bureaucrats are not elected. The underlying argument links to a more basic conception of legitimacy based on 'the extent to which [individuals] legitimately represent, or can successfully claim to represent, some group or larger set of social interests' (Saward 2005: 179; Saward 2010, 2014). Since the existence of representative claims is central to establishing democratic institutions' legitimacy (Kröger and Friedrich 2013; Riccucci et al. 2014), the contention advanced here is that administrative representation can 'operate as a legitimacy enhancer' (Gravier 2013: 833). The legitimacy of the EU institutions should thus be measured also in terms of the 
(un)representativeness of the administrative staff involved in its policy-making - what Olsen (2006: 3) calls 'administrative legitimacy'.

Since the representativeness of public administrations increases 'when the identity of the bureaucrat matches that of the client' (Riccucci et al. 2014: 537), 'administrative legitimacy' can be operationalized by measuring the extent to which the policy preferences of policy makers reflect those of the wider population. If EU policies should be supported by a majority of its citizens (as argued by Follesdal and Hix 2006) and representation is 'about giving accurate information on the constituents' preferences' (Piattoni 2013: 233), this is an important measure. Hence, although the traditional representative bureaucracy literature emphasizes the importance of public bureaucracies reflecting the communities that they serve in ascriptive terms, the extent to which bureaucrats share the same policy preferences as the wider population may provide a stronger measure of representativeness.

Although such a concept of administrative legitimacy may appear to be at odds with the impartiality requirement implicit in ideal-type Weberian bureaucratic decision-making (Weber 1978; Olsen 2006), three points are important. The first is that the Weberian idealtype has rarely been achieved in practice. Second, the desirability of Weberian dualism has been challenged even in theory. Third, recognition of expertise as a basis of the bureaucrat's claim to legitimacy need not be inconsistent with the representative requirement. Hence, the concept of administrative legitimacy suggests a new metric for assessing the democratic credentials of the EU: namely, the extent to which the policy preferences of EU civil servants reflect those of their compatriots at home.

\section{New understandings of representation and liberal democracy}

Government accountability is conventionally taken to be established via regular, free and fair elections in which incumbents are ousted when the populace deems their performance 
unsatisfactory (Curtin et al. 2010; Montanaro 2012; Kröger and Friedrich 2013). In lamenting the role and power in EU policy-making of unelected executive agents and indirectly elected European parliamentarians, much of the existing literature on the EU's democratic deficit falls into this traditional framework.

Yet, recent theoretical scholarship on representation and legitimacy expresses a need 'to enlarge the conceptualisation of democratic representation beyond elections' (Kröger and Friedrich 2013: 163; see also Rothstein 2009; Peters 2010). This new literature is premised on the view that 'a range of actors (...), elected as well as unelected ones, may succeed in making effective representative claims' (Saward 2014: 731; Montanaro 2012). This line of argument is particularly relevant when the traditional territorial state - in which the standard view of electoral accountability and legitimacy has greatest validity - is challenged (Curtin et al. 2010; Lord and Pollak 2010; Olsen 2013). The European Union itself provides a salient example of such a setting, and thus is a candidate for exploration using an expanded conceptualisation of democratic legitimacy based on 'non-elective modes of representation' (Saward 2014: 733; Montanaro 2012).

The shift to non-elective modes of representation requires reconfiguration of the 'conceptual tools [required] to assess if, and when, non-electoral forms of representation can be democratically legitimate' (Montanaro 2012: 1106). This paper focuses on public bureaucracy as one non-elective mode of representation. The choice derives from the fact that 'public bureaucracy is becoming an increasingly important locus for democratic activity' (Peters 2010: 209; Rothstein 2009). EU administrators, for instance, are key players in the policy-making process, and are involved in all stages of the policy cycle. Moreover, public administrations are likely to represent this 'institutional core' behind governmental effort into the foreseeable future (O'Toole 1997). As such, an in-depth exploration of the extent to which administrations 'can contribute to the achievement of democratic governance' (O'Toole 1997: 
$458)$ is required. Since bureaucratic autonomy is 'an organizational principle rooted in (...) the principle of separation of powers' (Olsen 2006: 9), public administrations can influence policy outcomes via the legitimate use of bureaucratic discretion (Pollack 2003; Jabko 2006; Olsen 2006; Schafer 2014) - a further reason for a focus on their democratic credentials.

The key question, however, is how public administrations can create political legitimacy. Building on the representative bureaucracy literature, this paper argues that 'administrative legitimacy' (Olsen 2006: 3) is likely to arise from the representativeness of the administrative staff. Making sure that all relevant groups are present in decision-making processes can raise popular acceptance levels, and may thereby become 'a possible instrument of legitimacy' (Gravier 2013: 820). The crucial insight is that civil servants can be responsive to the desires of the public simply because they themselves think and behave in a similar manner. That is, as argued by Mansbridge (2009: 369-70), representatives ideally 'already have policy goals much like the constituents'. This is important as democratic governance requires responsiveness to policy public preferences (O'Toole 1997; Scharpf 2006; Rothstein 2009), which can therefore constitute an important source of legitimacy for public administrations (Olsen 2006).

The degree to which public administrations (and administrators) 'can successfully claim to represent some group or larger set of social interests' (Saward 2005: 179; Saward $2010,2014)$ - and thereby achieve administrative legitimacy - thus depends on the overlap of their policy preferences with the relevant constituent population. In the representative bureaucracy literature, this intersection - usually constrained to socio-demographic factors, but here extended to policy preferences (see also Murdoch et al. 2016) - is known as passive or descriptive representation. It is differentiated from active or substantive representation, which refers to action in the interest, or on behalf, of the represented (Pitkin 1967; Mosher 
1968). The analysis presented in this paper rests solely on the passive overlap between the policy preferences of public officials and the broader population. ${ }^{2}$

\section{HOW REPRESENTATIVE? AN EMPIRICAL MODEL}

To operationalise the concept of administrative legitimacy, two complementary measures are proposed. The first rests on the idea that whenever one group (e.g., Belgian citizens) wants more/less of a certain policy relative to some other group (e.g., Irish citizens), public administrators representing these groups should - at the very least - replicate this preference ordering. This implies evaluating the cross-sectional correlation in the policy preferences expressed by EU administrators from a particular country and their country's population. ${ }^{3} \mathrm{~A}$ positive correlation between the position of public officials and their principals along some policy scale represents a minimal requirement for administrative legitimacy.

A key issue at this point concerns the choice of the appropriate reference group in the EU setting: i.e. should Commission administrators' policy preferences reflect those of the population in their home country, or those of the EU population as a whole? The former approach would require assessing whether Commission officials can claim legitimacy relative to their home country constituencies, though not necessarily to the overall EU population (and vice versa for the latter approach). Although important theoretically, this choice has no direct methodological implications. The empirical analysis below takes member state populations as the key reference groups because EU legitimacy is 'normatively constrained by the basic compliance-legitimacy relationship between member governments and their constituencies' (Scharpf 2009: 173). In other words, the key issue is the extent to which the EU assists member states to 'meet their own obligations to their own publics', because the legitimacy of the EU can 'be indirectly derived from that of its national democracies where any obligations it helps meet are those of national democracies themselves' (Lord 2015: 5-6). Yet, the 
methodological equivalence brought forward here implies that future studies can be developed taking the EU population as a whole as the reference group.

A positive correlation between two sets of policy preferences need not necessarily imply that public officials from certain countries are 'closer' in a spatial sense to their home population than public officials from other countries. Yet, a larger 'distance' between the preferences of public administrators and their principals may weaken public officials' claim to represent popular preferences. To capture more explicitly this spatial dimension of administrative legitimacy, our second operationalization calculates the Euclidian distance between the position of EU administrators and European citizens in a multi-dimensional policy space. The Euclidean distance between two points is essentially the length of a straight line connecting them. Imagine that these two 'points' are the policy preference vectors of an EU administrator $(B U R)$ and the broader population $(P O P)$ along a number of dimensions $(j=1, \ldots, J)$ in the multi-dimensional policy space: $\left(B U R_{1}, B U R_{2}, \ldots, B U R_{J}\right)$ and $\left(P O P_{1}\right.$, $\left.P O P_{2}, \ldots, P O P_{J}\right)$. The distance between both sets of policy preferences can then be calculated for each public official $i$ as:

$$
\operatorname{DISTANCE} E_{i}=\sqrt{\sum_{j=1}^{J}\left(B U R_{j}-P O P_{j}\right)^{2}}
$$

Hooghe (2003) similarly calculates the difference between the policy preferences of Commission officials and the EU population on a policy-by-policy basis to study relative support for EU policies between European elites and public opinion. Equation (1) generalises this approach to a multi-dimensional policy setting. Smaller numbers imply that the two sets of preferences lie closer together in the multidimensional policy space, such that EU officials can at least to some extent claim to represent the population's underlying policy preferences (in the sense of Saward 2005, 2010) - and thereby achieve administrative legitimacy.

This spatial approach is also close in spirit to the procedure proposed by Tsebelis et al. (2001) for assessing the degree of adoption of European Parliament amendments in co- 
decision procedures. Tsebelis et al. (2001) code the degree of amendment adoption on a fivepoint scale (i.e. adopted, largely adopted, partially adopted, modified, not adopted), depending on how extensively the draft legislations changed in line with amendments proposed. As such, they essentially measure the 'distance' between the preferences of the European Parliament and the final agreement in a multi-dimensional 'amendment space'.

\section{EMPIRICAL ANALYSIS}

\section{Data and operationalisation}

To assess how including administrative legitimacy affects the EU's legitimacy shortfall, we draw on a unique new dataset that combines information from Eurobarometer surveys of public opinion with information collected via two web-based surveys among EU civil servants. Both surveys generated comprehensive information about respondents' policy preferences, but this paper concentrates on preferences regarding the appropriate level of decision-making within the EU as an issue of sovereignty (i.e. the authority to adjust the content of a given policy), rather than preferences towards specific public policy programmes. This choice was driven by three main considerations (for a similar approach, see Hooghe 2003; Schafer 2014; Trondal et al. 2015). The first is that individuals' ideological leaning is likely to affect their policy preferences, while such impact is weaker for opinions concerning the costs/benefits of EU integration. Second, preferences towards EU- or national-level policy-making are important independently of preferences regarding specific policies or decisions (Hooghe 2003). Finally, EU-level decision-making as an issue of sovereignty remains high on the political agenda and is often fiercely debated (Hobolt 2014; Murdoch and Geys 2014). This makes it an important issue from the perspective of the (administrative) legitimacy of the EU. 
The opinion of European citizens towards the EU polity and its activities is measured using Eurobarometer data. As an individual's stance towards the EU may vary across policy areas, the approach here is to follow Hooghe (2003) in focusing on a Eurobarometer question that specifically refers to various policy areas: 'For each of the following areas, do you think that decisions should be made by the national government, or made jointly within the European Union?'. Support for the first half of the statement (and thus in favour of national policy-making) is coded as value 1, while support for the latter half of the statement (and thus in favour of $E U$ policy-making) is coded as value 2. The question is repeated for 18 policy areas (including 'fighting crime', 'taxation', 'defence and foreign affairs', 'immigration', 'health and social welfare', and 'the educational system'). This makes it possible to calculate the share of a country's population that favours/opposes EU-level decision-making for each policy area - as well as an average preference across all policy areas. Our coding of public attitudes thus reflects the population share of a given country holding a specific opinion. To prevent the recent economic recession from affecting this measurement, we use information from the last Eurobarometer before the onset of the on-going financial crisis (Eurobarometer 67.2 from 2007). ${ }^{4}$

To measure Commission officials' preferences towards the EU polity, data was collected via a unique web-based survey administered between January and April 2011 to all 1098 then-active Seconded National Experts (SNEs) in the European Commission. The sample available for the present analysis consists of 379 respondents (approximately $35 \%$ of the total SNE population), and is representative in terms of age and gender. Its distribution across Directorate-Generals also reflects that observed for all Commission SNEs in 2011 (see also Murdoch and Trondal 2013; Trondal et al. 2015; Murdoch et al. 2016). To measure SNEs' attitudes towards the EU project, the survey included a question asking: 'Before entering the Commission, did you generally think that co-operation within the EU was 
advantageous or disadvantageous?' This question was asked both 'in general' and 'within your portfolio', and responses were recorded on a five-point scale from (1) 'advantageous' to (5) 'disadvantageous'. Our coding of SNEs' attitudes thus reflects their position on two fivepoint scales. Although the phrasing of this question is not identical to that employed in the Eurobarometer survey, both questions concur in terms of their inference regarding the (dis)advantages of EU-level cooperation. This provides sufficient overlap in the meaning of both questions for it to be employed here.

The second dataset was collected in 2008 as part of the 'European Commission in Question' (EUCIQ) project, which investigated the internal operation of the Commission as well as the backgrounds, beliefs and careers of its officials (Kassim et al., 2013). The data collection targeted a representative sample of 4621 Commission officials selected from the Commission's 14000-strong permanent administrative staff in policy DGs (excluding translation/linguistics). Similar to the Eurobarometer and SNE surveys, the EUCIQ survey contains a question asking: 'We are interested in your views on the distribution of authority between member states and the EU on a range of policies. Where should this policy be decided?' This question was asked for 11 policy areas ('agriculture', 'energy policy', 'social policy', 'development policy', 'regional development', 'competition policy', 'environmental policy', 'foreign and defence policy', 'asylum and immigration', 'trade policy', and 'police and judicial cooperation'), and responses were recorded on an 11-point scale from (0) 'exclusively national/subnational' to (10) 'exclusively EU'. This question achieved 1618 valid responses (approximately $35 \%$ of the sampled population), and can be employed to measure the attitudes of permanent Commission staff towards the EU project (Kassim et al. 2013; Schafer 2014). Our coding of permanent Commission staff's attitudes thus reflects their position on these eleven eleven-point scales (as well as their average position across all eleven policy areas). 


\section{Results for Seconded National Experts}

Table 1 reports pairwise correlations between the preferences expressed by seconded EU administrative staff and their member states' populations regarding the desirability of (increased) EU-level decision-making in public policies. ${ }^{5}$ In column 1, the policy preferences of the SNE sample refer to their feeling about EU cooperation 'in general', while popular preferences are an unweighted average across all policy areas presented in the Eurobarometer survey. The remaining columns in table 1 analyse preferences specific to public policy programmes linked to six Directorate-General clusters (i.e. Market, External Relations, Social Regulation, Supply, Provision and Research; see note to table 1 for details). While clustering different policy programmes into Directorate-General clusters is necessary to retain sufficient observations among our set of SNEs for each policy area (see bottom row of table 1), the policy preferences of the SNE sample in this case refer to their feeling about EU cooperation 'within your portfolio'. These are then linked to the share of a country's population that opposes EU-level decision-making in policy areas of relevance to that particular DirectorateGeneral.

Table 1 about here

The results in table 1 indicate that when the share of citizens in SNEs' country of origin with positive (negative) attitudes towards the EU increases, SNEs from that country tend to also express a more positive (negative) opinion about cooperation within the EU in general (column 1). This positive correlation is statistically significant at the $90 \%$ confidence level. Furthermore, the remaining columns of table 1 indicate that the same positive correlation arises in four out of six policy areas. On the whole, therefore, this fairly consistent correlation 
between public officials' policy preferences and those of their home country populations implies that EU officials can at least to some extent claim to represent their home country population - and thereby achieve some degree of administrative legitimacy.

Interestingly, the overall positive correlation observed in column 1 appears largely driven by the statistically highly significant - and substantively strong - positive correlation observed for the 'external relations' (and, to a lesser extent, the 'social regulation') portfolio. While the exact mechanism driving these results can, unfortunately, not be established based on our current data, this observation at least suggests that there rests a more stringent legitimacy requirement or constraint (in the sense of Scharpf 2009) on public officials dealing with 'contentious issues such as foreign affairs and social policies' (Schafer 2014: 912). These policy areas have also witnessed less integration. A higher degree of administrative legitimacy could thus be employed to counter potential fears that decisions at the European level in these policy areas are 'not subject to the same controls as decisions at the national level' (Andreatta 2011: 34).

One might also wonder whether the results in table 1 are particularly strong/weak for certain countries. Since a country-specific analysis is impossible due to the very limited number of individuals from any given member state, we replicate the analysis for three country-clusters: i.e. countries in the original EU6 (Belgium, France, Germany, Italy, the Netherlands, and Luxembourg), the nine countries joining prior to 2004 (referred to as 'EU9': Austria, Denmark, Finland, Greece, Ireland, Portugal, Spain, Sweden, and United Kingdom), and the twelve countries from the most recent enlargement rounds (referred to as 'EU10+2': Bulgaria, Cyprus, Czech Republic, Estonia, Hungary, Latvia, Lithuania, Malta, Poland, Romania, Slovakia and Slovenia). The results suggest that the correlation between public officials' policy preferences and those of their home country populations is positive and statistically significant only for EU9 countries $(\mathrm{r}=0.263, \mathrm{p}<0.001$; details available upon 
request). Hence, the overall positive correlation documented in table 1 appears driven by respondents from the EU9 countries. One possible reason is that these countries' decisions to enter the EU followed a period of observation from the periphery of how the European Community functioned, and was based on a strategic calculus rather than a primordial response to the experience of war (as for the original Six; e.g. Gerber [1994]) or a reaction to new-found independence and a desire to re-join 'Europe' (as for many of the EU10+2; e.g. Schimmelfennig and Sedelmeier [2005]). In other words, the politics of EU membership differed significantly for the EU9, and followed repeated and protracted debates concerning the 'sovereignty bargain' inherent to the European integration process (Litfin 1997; Mattli 2000). ${ }^{6}$ This can be expected to impose a more stringent legitimacy requirement on public officials from such countries.

\section{Results for permanent Commission administrative staff}

Table 2 turns to the EUCIQ dataset (Kassim et al. 2013), and reports pairwise correlations between the preferences expressed by permanent Commission officials and the broader population regarding the desirability of EU-level decision-making. Like table 1, the top row looks at feelings towards EU-level cooperation in general, with the preferences of EU officials as well as the general population representing unweighted averages across all policy areas. The first column again takes into account all available respondents, whereas the remaining columns constrain the analysis to respondents within six specific Directorate-General clusters (i.e. Market, External Relations, Social Regulation, Supply, Provision and Central; see note to table 2). ${ }^{7}$ The remaining rows of table 2 analyse policy preferences specific to nine detailed policy programmes brought forward in both the EUCIQ and Eurobarometer surveys.

Table 2 about here 
The results in the top row of table 2 again indicate that when the share of citizens in permanent Commission officials' country of origin with positive (negative) attitudes towards the EU increases, Commission officials from that country tend to also express a more positive (negative) opinion about cooperation within the EU in general (row 1, column 1). Interestingly, the size of the pairwise correlation is nearly equivalent to that observed in table $1(0.078$ versus 0.086$)$. The remaining columns in the top row of table 2 are likewise in close accordance with the results reported in table 1 . We again find a particularly strong positive correlation for respondents in the 'external relations' portfolio, though in this case we also observe a strong positive correlation for respondents in the 'provision' portfolio. Separating respondents by their country of origin, we also again uncover a statistically significant correlation only for EU9 countries $(\mathrm{r}=0.198, \mathrm{p}<0.001$; details available upon request). These findings not only corroborate the robustness of our results across independent datasets, but also - with relatively small deviations - across different types of Commission staff.

Importantly, the EUCIQ data allow us to take the analysis a step further, and look at the correlations of policy preferences at the level of specific policies. Extending our analysis in this way generates only a limited number of statistically significant correlations (see rows 2 to 10 in table 2). Clearly, some significant connections will arise purely due to chance when calculating a substantial number of correlation coefficients (i.e. 63 in our case). Yet, it is noteworthy that all but two of the significant correlations in table 2 are positive, whereas finding positive or negative significant correlations should be equally likely if they arose purely due to chance. Moreover, the significant positive correlations once again arise nearexclusively in the more contentious policy issues under analysis: i.e. foreign policy, social policy and immigration. These results thus are in close accordance with those obtained above, 
which strengthens our confidence in the idea that contentious policy areas appear to induce a more stringent legitimacy requirement on public administrators in the Commission.

Having access to preferences expressed at the level of specific policies also enables calculation of the Euclidian distance between the policy-preference vectors of EU public administrators and the population in their member states. As mentioned, this complements the correlational approach by focusing on the spatial dimension of administrative legitimacy. The empirical approach here proceeds in two steps. The first is calculation of the Euclidian distance between Commission officials' policy preferences and those of their home country population for all 1618 individuals in our sample. The second is to average the obtained distances for all respondents in each of the six Directorate-General clusters, and for all public policies. The results are reported in table 3 .

The most important information contained in table 3 refers to the relative size of the observed distances in the multidimensional policy space across DG clusters and public policies. This highlights which sections of the Commission are 'closer' to the policy preferences expressed by EU officials' home country populations, which is informative even though the calculated absolute distances arguably lack a strong substantive meaning. We therefore also report the statistical significance of the difference between the mean of the distance measure in a given DG cluster (columns 2 to 7) and the mean of the distance measure calculated across all EU administrators (column 1). The asterisks in table 3 represent this additional information. Table 3 employs the same format as table 2: the top row displays the average Euclidian distance obtained for Commission officials in general (column 1) and within the six DG clusters separated in table 2 (columns 2 to 7 ). The remaining rows contain results by policy area, again calculated across all Commission officials and by DG clusters.

Table 3 about here 
The results in table 3 indicate that there are only eight statistically significant differences between the average distance measure in a given DG cluster (columns 2 to 7 ) and the average distance measure calculated across all officials (column 1): four each at the $90 \%$ and $95 \%$ confidence levels. This is a low number given that 60 tests were performed and that the tests are not fully independent (since a lower average distance in one DG cluster compared to the average distance across all Commission officials must be 'compensated' by a larger average distance in at least some other DG clusters). The findings therefore suggest that there do not appear to be particular subsets of Commission officials - defined either in terms of their policy area or DG cluster - that are located particularly 'close' in policy space to their home country population. In other words, even though Commission officials' policy preferences on the whole are positively correlated with those of their home country populations (see table 1 and 2), this does not imply that certain subsets of EU public officials are located closer in a spatial sense to their home country populations. While such country-specific policy closeness can help administrators to act as a 'national legitimating mechanism' for the normative and political powers exercised by the EU (Lindseth 2010: 14), its absence might also be viewed as good news for the Commission. Indeed, while some degree of administrative legitimacy is obtained from the positive correlation in the policy preferences of EU administrators and their home countries, the lack of strong patterns in the calculated Euclidian distances suggests the absence of country-specific policy biases that might be challenging the autonomy of the institution as a whole.

\section{CONCLUSION}

This paper has sought to make three contributions to the literature on the EU's 'democratic deficit'. The first is the argument that administrative legitimacy, which has so far been absent 
from the EU debate, needs to be applied in consideration of the EU's democratic credentials. Such administrative legitimacy should be factored in as an important criterion of the EUs' input legitimacy besides electoral accountability. Second, although the EU's ratings may not match national political systems on the standard measure of electoral accountability or the existence of a demos, our analysis of original data illustrates that the European Commission scores much better on the representative bureaucracy dimension. This finding stands in direct contradiction to the popular view that the EU is undemocratic specifically on account of the Commission's status and influence.

Our third contribution speaks to the literature on representative bureaucracy rather than on the EU's democratic deficit. The measure used in this paper to demonstrate the representativeness of the Commission - i.e. the sharing of policy preferences - is new and novel. Historically, the representative bureaucracy literature has contended that an administration should reflect the ethnic, linguistic, national and/or gender composition of the wider community that it serves. The measure introduced in this paper goes a step further. It suggests that it is not sufficient for a public bureaucracy to look like the wider community, but that within its workforce there must be staff members who think like them.

It is important, however, to observe that our analysis of administrative legitimacy is based on an objective standard of representation rather than citizen's subjective perception thereof. This is important since it may be less straightforward at the EU level - compared to, say, the national or subnational level - for citizens to recognise whether their preferences are effectively represented. Such subjective aspect of administrative legitimacy - i.e. citizens' de facto recognition of their bureaucratic representation - is an important avenue for further research. The same is true for the closely related question whether EU officials effectively and actively pay attention to their national publics. Finally, the limitations of our data did not 
allow conclusive results regarding possible heterogeneity across policy areas. Future work should explore this in more detail.

Biographical notes: Zuzana Murdoch is Associate Professor in Public Administration at University of Agder, Norway. Sara Connolly is Professor in Personnel Economics at Norwich Business School, United Kingdom. Hussein Kassim is Professor in Politics at University of East Anglia, United Kingdom.

Addresses for correspondence: Zuzana Murdoch, Department of Political Science, University of Agder, Postbox 422, NO-4604 Kristiansand, Norway. Email: zuzana.murdoch@uia.no / Sara Connolly, Norwich Business School, University of East Anglia, United Kingdom. Email: sara.connolly@uea.ac.uk / Hussein Kassim, School of Politics, Philosophy, Language and Communication Studies, University of East Anglia, United Kingdom. Email: h.kassim@uea.ac.uk.

\section{ACKNOWLEDGEMENTS}

We are grateful to two anonymous referees, Åse Gornitzka, Guy Peters, Guri Rosen, Helene Sjursen, and participants of the 2015 EUSA meeting for helpful comments. The first author gratefully acknowledges Matthew Snoding (CLENAD) and Nina Bonge for invaluable assistance with the survey among Commission's Seconded National Experts. This article draws on data collected as part of 'The European Commission in Question' project funded by the UK Economic and Social Research Council (grant no. RES-062-23-1188), and conducted by Hussein Kassim (PI), John Peterson (Co-I), Andrew Thompson (Co-I), Michael Bauer, Sara Connolly, Renaud Dehousse, and Liesbet Hooghe. See http://www.uea.ac.uk/psi/research/EUCIQ for further information. 


\section{NOTES}

${ }^{1}$ In the foregoing literature, legitimacy is measured predominantly in terms of either policy outcomes ('output' legitimation; Majone 1998) or active citizen involvement in decisionmaking processes ('input' legitimation; Bellamy and Castiglione 2003; Hix 2008). Schmidt (2013: 2) recently added a third factor - called 'throughput legitimacy' - which requires judgment "in terms of the efficacy, accountability and transparency of the EU's governance processes along with their inclusiveness and openness to consultation with the people."

${ }^{2}$ Although attitudinal similarity (i.e. passive representation) may be a necessary condition for active representation, it is certainly not a sufficient condition for acting upon those shared attitudes (Selden 1997; Sowa and Selden 2003). Hence, passive and active representation need not necessarily be causally connected. Even so, recent work often does find they are closely connected (Murdoch et al. 2016). This raises the potential concern that Commission officials following the active representation model might not be doing their jobs as supranational officials. Indeed, any potential lack of autonomy from member states is a key concern for international bureaucrats, since "what is at stake here is the very concept of an impartial ICS [i.e. International Civil Service]" (Mouritzen 1990: 35-36). For recent contributions on this autonomy issue among Commission officials, we refer to Ellinas and Suleiman (2012) and Trondal et al. (2015), while Weiss (2013) provides a discussion with respect to the same issue within the United Nations.

${ }^{3}$ The same approach allows evaluating increasing/decreasing legitimacy via administrative representation over time. That is, whenever (a segment of) the European population expresses increasing demands over time in favour of a certain policy, a minimal requirement 
for administrative legitimacy would require that (a segment of) Commission officials likewise shows this temporal ordering of policy preferences.

${ }^{4}$ As an alternative measure of European citizens' overall preference towards European-level policy-making, we also exploit the question: "Generally speaking, do you think (your country's) membership is a good thing, a bad thing, neither good nor bad?". This allows calculating the share of a country's population answering that EU membership is a 'bad thing'. All results below are qualitatively similar using this alternative question (details upon request).

${ }^{5}$ As the dataset for SNEs does not include public officials' opinion towards EU-level decision-making across a range of policy areas, we cannot calculate the Euclidian distance measure. Hence, we here only perform the correlational analysis.

${ }^{6}$ The concept of 'sovereignty bargains' refers to the trade-off in regional integration processes between countries' reduced autonomy and the expected benefits from increased security, economic prosperity and/or political power.

${ }^{7}$ We exclude the Directorate-General cluster 'Research' as this cluster contains only 31 observations. Instead, we can include an alternative cluster of 'Central' Directorates-General - which was impossible in table 1 due to the limited number of SNEs from such Directorates-General in our SNE sample. 


\section{REFERENCES}

Andreatta, F. (2011) 'The European Union's international relations: A theoretical view', in Ch. Hill and M. Smith (eds.), International Relations and the European Union, Oxford: Oxford University Press, pp. 21-43.

Bellamy, R. and Castiglione, D. (2003) 'Legitimizing the Euro-polity and its regime', European Journal of Political Theory 2(1): 7-34.

Curtin, D., Mair, P. and Papadopoulos, Y. (2010) 'Positioning accountability in European governance: An introduction', West European Politics 33(5): 929-45.

Ellinas, A.A. and Suleiman, E. (2012) The European Commission and Bureaucratic Autonomy: Europe's Custodians, Cambridge: Cambridge University Press.

Follesdal, A. and Hix, S. (2006) 'Why there is a democratic deficit in the EU: A response to Majone and Moravcsik', Journal of Common Market Studies 44(3): 533-62.

Gerber, P. (1994) La Construction Européenne, Paris: Collection notre siècle.

Gravier, M. (2013) 'Challenging or enhancing the EU's legitimacy? The evolution of representative bureaucracy in the Commission's staff policies', Journal of Public Administration Research and Theory 23: 817-38.

Hix, S. (2008) What's Wrong with the European Union and How to Fix It, Cambridge: Polity Press.

Hobolt, S.B. (2014) 'Ever closer or ever wider? Public attitudes towards further enlargement and integration in the European Union', Journal of European Public Policy 21(5): 664-80.

Hooghe, L. (2003) 'Europe Divided? Elites versus Public Opinion on European Integration', European Union Politics 4: 281-304.

Jabko, N. (2006) Playing the Market: A Political Strategy for Uniting Europe, Ithaca: Cornell University Press. 
Kassim, H., Peterson, J., Bauer, M.W., Connolly, S., Dehousse, R., Hooghe, L., Thompson, A. (2013) The European Commission of the 21st Century, Oxford: Oxford University Press.

Kohler-Koch, B. (2010) 'Civil society and EU democracy: 'Astroturf' representation?', Journal of European Public Policy 17(1): 100-16.

Kröger, S. and Friedrich, D. (2013) 'Introduction: The representative turn in EU studies', Journal of European Public Policy 20(2): 155-70.

Litfin, K. (1997) 'Sovereignty in world politics', Mershon International Studies Review 41: 167-204.

Lindseth, P. (2010) Power and Legitimacy: Reconciling Europe and the Nation State, Oxford: Oxford University Press.

Lord, C. (2015) 'An indirect legitimacy argument for a directly elected European Parliament', University of Oslo, Mimeo.

Lord, C. and Pollak, J. (2010) 'The EU's many representative modes: Colliding? Cohering?', Journal of European Public Policy 17(1): 117-36.

Majone, G. (1994) 'The rise of the regulatory state in Europe', West European Politics 17(3): 78-102.

Majone, G. (1998) 'Europe's “democratic deficit”: The question of standards', European Law Journal 4(1): 5-28.

Mansbridge, J. (2009) 'A selection model of political representation', Journal of Political Philosophy 17(4): 369-98.

Mattli, W. (2000) 'Sovereignty bargains in regional integration', International Studies Review 2(2): $149-80$.

Montanaro, L. (2012) 'The democratic legitimacy of self-appointed representatives', Journal of Politics 74(4): 1094-107. 
Moravcsik, A. (2002) 'In defence of the "democratic deficit": Reassessing the legitimacy of the European Union', Journal of Common Market Studies 40(4): 603-34.

Moravcsik, A. (2004) 'Is there a "democratic deficit" in world politics? A framework for analysis', Government and Opposition 39(2): 336-63.

Mosher, F.C. (1968) Democracy and the Public Service, Oxford: Oxford University Press.

Mouritzen, H. (1990) The International Civil Service. A Study of Bureaucracy: International Organizations, Aldershot: Dartmouth.

Murdoch, Z. and Trondal, J. (2013) 'Contracted government: Unveiling the European Commission's contracted staff', West European Politics 36(1): 1-21.

Murdoch, Z. and Geys, B. (2014) 'Institutional dynamics in international organisations: Lessons from the recruitment procedures of the European External Action Service (EEAS)', Organization Studies 35(12): 1793-811.

Murdoch, Z., Trondal, J. and Geys, B. (2016) 'Representative bureaucracy and seconded national government officials in the European Commission', Regulation and Governance forthcoming.

Olsen, J.P. (2006) 'Maybe it is time to rediscover bureaucracy', Journal of Public Administration Research and Theory 16(1): 1-24.

Olsen, J.P. (2013) 'The institutional basis of democratic accountability', West European Politics 36(3): 447-73.

O’Toole, L.J. (1997) 'The implications for democracy in a networked bureaucratic world', Journal of Public Administration Research and Theory 7: 443-59.

Peters, B.G. (2010) ‘Bureaucracy and democracy', Public Organization Review 10: 209-22.

Piattoni, S. (2013) 'Representation as delegation: A basis for EU democracy?', Journal of European Public Policy 20(2): 224-42.

Pitkin, H.F. (1967) The Concept of Representation, Berkeley: University of California Press. 
Pollack, M. (2003) The Engines of European Integration: Delegation, Agency and Agenda Setting in the EU, Oxford: Oxford University Press.

Riccucci, N.M., van Ryzin, G.G. and Lavena, C.F. (2014) 'Representative bureaucracy in Policing: Does it increase perceived legitimacy?', Journal of Public Administration Research and Theory 24: 537-51.

Rothstein, B. (2009) 'Creating political legitimacy: Electoral democracy versus quality of government', American Behavioral Scientist 53(3): 311-30.

Saward, M. (2005) 'Governance and the transformation of political representation', in J. Newman (ed.), Remaking Governance: Peoples, Politics and the Public Sphere, Bristol, UK: Policy Press, pp. 179-96.

Saward, M. (2010) The Representative Claim, Oxford: Oxford University Press.

Saward, M. (2014) 'Shape-shifting representation', American Political Science Review 108(4): 723-36.

Schafer, J. (2014) 'European Commission officials' policy attitudes', Journal of Common Market Studies 52(4): 911-27.

Scharpf, F.W. (2006) 'Problem solving effectiveness and democratic accountability in the EU', IHS Political Science Series nr. 107.

Scharpf, F.W. (2009) 'Legitimacy in the multilevel European polity', European Political Science Review 1(2): 173-204.

Schimmelfennig, F. and Sedelmeier, U. (2005) The Europeanization of Central and Eastern Europe, Ithaca: Cornell University Press.

Schmidt, V.A. (2013) 'Democracy and legitimacy in the European Union revisited: Input, output and throughput', Political Studies 61: 2-22.

Selden, S.C. (1997) The Promise of Representative Bureaucracy, New York: M.E. Sharpe. 
Sowa, J.E. and S.C. Selden (2003) 'Administrative discretion and active representation: An expansion of the theory of representative bureaucracy', Public Administration Review 63(6): $700-9$.

Trondal, J., Murdoch, Z. and Geys, B. (2015) 'On Trojan horses and revolving doors: Autonomy of seconded national officials in the European Commission', European Journal of Political Research 54(2): 249-70.

Tsebelis, G., Jensen, C.B., Kalandrakis, A. and Kreppel, A. (2001) 'Legislative procedure in the European Union: An empirical analysis’, British Journal of Political Science 31(4): 57399.

Waldo, D. (1952) 'Development of a theory of democratic administration', American Political Science Review 46(1): 81-103.

Weber, M. (1978) Economy and Society, Berkeley: University of California Press.

Weiss, T.G. (2013) 'Reinvigorating the 'second' United Nations: People matter', in B. Reinalda (ed.), Routledge Handbook of International Organization, New York: Routledge, pp. 299-311.

Wille, A. (2010) 'Political-bureaucratic accountability in the EU Commission: Modernising the executive', West European Politics 33(5): 1093-116. 


\section{APPENDIX: ACRONYMS OF COMMISSION DIRECTORATES-GENERAL AND SERVICES}

\section{Directorate-Generals}

Agriculture and Rural Development (AGRI)

Budget (BUDG)

Climate Action (CLIMA)

Communication (COMM)

Communications Networks, Content and Technology (CNECT)

Competition (COMP)

Economic and Financial Affairs (ECFIN)

Education and Culture (EAC)

Employment, Social Affairs and Inclusion (EMPL)

Energy (ENER)

Enlargement (ELARG)

Enterprise and Industry (ENTR)

Environment (ENV)

EuropeAid Development \& Cooperation (DEVCO)

Eurostat (ESTAT)

Health and Consumers (SANCO)

Home Affairs (HOME)

Humanitarian Aid (ECHO)

Internal Market and Services (MARKT)

Joint Research Centre (JRC)

Justice (JUST) 
Maritime Affairs and Fisheries (MARE)

Mobility and Transport (MOVE)

Regional Policy (REGIO)

Research and Innovation (RTD)

Service for Foreign Policy Instruments (FPI)

Taxation and Customs Union (TAXUD)

Trade (TRADE)

\section{Services}

Bureau of European Policy Advisers (BEPA)

European Anti-Fraud Office (OLAF)

Internal Audit Service (IAS)

Legal Service (SJ) 
Table 1: Pairwise correlations between preferences of Commission SNEs and member state populations

\begin{tabular}{|l|c|c|c|c|c|c|c|}
\hline & General & Market & $\begin{array}{c}\text { External } \\
\text { Relations }\end{array}$ & $\begin{array}{c}\text { Social } \\
\text { Regulation }\end{array}$ & Supply & Provision & Research \\
\hline $\begin{array}{l}\text { Correlation } \\
(\mathrm{p} \text {-value })\end{array}$ & $\begin{array}{c}0.086^{*} \\
(\mathrm{p}=0.096)\end{array}$ & $\begin{array}{c}-0.035 \\
(\mathrm{p}=0.789)\end{array}$ & $\begin{array}{c}0.346^{* * *} \\
(\mathrm{p}=0.009)\end{array}$ & $\begin{array}{c}0.158 \\
(\mathrm{p}=0.126)\end{array}$ & $\begin{array}{c}0.089 \\
(\mathrm{p}=0.464)\end{array}$ & $\begin{array}{c}-0.274 \\
(\mathrm{p}=0.218)\end{array}$ & $\begin{array}{c}0.154 \\
(\mathrm{p}=0.317)\end{array}$ \\
\hline $\begin{array}{l}\text { Number of } \\
\text { SNEs }\end{array}$ & $\mathrm{N}=379$ & $\mathrm{~N}=61$ & $\mathrm{~N}=59$ & $\mathrm{~N}=94$ & $\mathrm{~N}=72$ & $\mathrm{~N}=23$ & $\mathrm{~N}=46$ \\
\hline
\end{tabular}

Note: Entries are pairwise correlations (with p-values indicating statistical significance in brackets). *** significant at 1\%, ** at 5\% and * at 10\%. 'Market' is Directorate-Generals COMP, ECFIN, ENTR and MARKT; 'External Relations' is Directorate-Generals ELARG, DEVCO, FPI, ECHO and TRADE; 'Social Regulation' is Directorate-Generals CLIMA, EAC, EMPL, ENV, SANCO, HOME and JUST; 'Supply' is Directorate-Generals ENER, CNECT, MOVE, RTD and TAXUD; 'Provision' is Directorate-Generals AGRI, MARE and REGIO; and 'Research' is DirectorateGenerals ESTAT and JRC (acronyms explained in appendix). 
Table 2: Pairwise correlations between preferences of Commission permanent administrative staff and member state populations

\begin{tabular}{|c|c|c|c|c|c|c|c|}
\hline & $\begin{array}{c}\text { All } \\
\text { officials }\end{array}$ & Market & $\begin{array}{c}\text { External } \\
\text { Relations }\end{array}$ & $\begin{array}{c}\text { Social } \\
\text { Regulation }\end{array}$ & Supply & Provision & Central \\
\hline $\begin{array}{l}\text { All policy areas } \\
\text { Correlation } \\
\text { (p-value) }\end{array}$ & $\begin{array}{c}0.078 * * \\
(0.002)\end{array}$ & $\begin{array}{c}0.066 \\
(0.309)\end{array}$ & $\begin{array}{c}0.166^{* *} \\
(0.013)\end{array}$ & $\begin{array}{c}0.005 \\
(0.933)\end{array}$ & $\begin{array}{c}0.073 \\
(0.198)\end{array}$ & $\begin{array}{l}0.191 * * \\
(0.011)\end{array}$ & $\begin{array}{c}0.103 \\
(0.245)\end{array}$ \\
\hline Agriculture & ns & ns & ns & ns & $\mathrm{ns}$ & ns & ns \\
\hline Competition & ns & $\begin{array}{c}-0.172 * * \\
(0.008)\end{array}$ & ns & ns & ns & ns & ns \\
\hline Crime/police & ns & ns & ns & ns & ns & ns & ns \\
\hline $\begin{array}{l}\text { Defence/foreign } \\
\text { policy }\end{array}$ & $\begin{array}{l}0.055 * * \\
(0.027)\end{array}$ & ns & $\begin{array}{l}0.112 * \\
(0.097)\end{array}$ & ns & $\begin{array}{l}0.103 * \\
(0.071)\end{array}$ & ns & $\begin{array}{l}0.172 * \\
(0.054)\end{array}$ \\
\hline Energy & $\begin{array}{c}0.072 * * \\
(0.004)\end{array}$ & ns & ns & ns & $\begin{array}{l}0.184 * * \\
(0.001)\end{array}$ & ns & ns \\
\hline Environment & $\mathrm{ns}$ & ns & ns & $\mathrm{ns}$ & ns & ns & $\begin{array}{l}-0.182 * \\
(0.042)\end{array}$ \\
\hline Immigration & $\begin{array}{c}0.093 * * \\
(0.000)\end{array}$ & ns & $\begin{array}{c}0.206 * * \\
(0.002)\end{array}$ & $\begin{array}{l}0.128 * * \\
(0.026)\end{array}$ & ns & ns & $\begin{array}{l}0.149 * \\
(0.096) \\
\end{array}$ \\
\hline Regional & ns & ns & ns & ns & ns & ns & ns \\
\hline $\begin{array}{l}\text { Unemployment/ } \\
\text { social policy }\end{array}$ & $\begin{array}{l}0.177 * * \\
(0.000)\end{array}$ & $\begin{array}{l}0.125^{*} \\
(0.054)\end{array}$ & $\begin{array}{c}0.264 * * \\
(0.000)\end{array}$ & $\begin{array}{l}0.219 * * \\
(0.000)\end{array}$ & $\begin{array}{l}0.174 * * \\
(0.002)\end{array}$ & $\begin{array}{l}0.146^{*} \\
(0.051)\end{array}$ & ns \\
\hline $\begin{array}{l}\text { Number of } \\
\text { observations }\end{array}$ & $N=1646$ & $\mathrm{~N}=242$ & $\mathrm{~N}=223$ & $\mathrm{~N}=305$ & $\mathrm{~N}=310$ & $\mathrm{~N}=178$ & $\mathrm{~N}=129$ \\
\hline
\end{tabular}

Note: Entries are pairwise correlations (with p-values indicating statistical significance in brackets); ** significant at 5\%,

* at 10\%, ns is not statistically significant. For division of Directorate-Generals, see note to table 1. 'Central' consists of BUDG, COMM, IAS, BEPA, SJ and OLAF (acronyms explained in appendix). 
Table 3: Euclidian distance between preferences of Commission permanent administrative staff and member state populations

\begin{tabular}{|l||c||c|c|c|c|c|c|}
\hline & $\begin{array}{c}\text { All } \\
\text { officials }\end{array}$ & Market & $\begin{array}{c}\text { External } \\
\text { Relations }\end{array}$ & $\begin{array}{c}\text { Social } \\
\text { Regulation }\end{array}$ & Supply & Provision & Central \\
\hline \hline All policy areas & 0.705 & 0.700 & 0.711 & 0.714 & 0.704 & 0.702 & 0.702 \\
\hline \hline Agriculture & 0.245 & 0.241 & 0.259 & 0.258 & 0.237 & 0.241 & 0.226 \\
\hline Competition & 0.210 & 0.204 & $0.228^{* *}$ & 0.208 & $0.197^{* *}$ & 0.212 & 0.220 \\
\hline Crime/police & 0.205 & 0.207 & 0.199 & 0.216 & 0.211 & 0.189 & 0.196 \\
\hline $\begin{array}{l}\text { Defence/foreign } \\
\text { policy }\end{array}$ & 0.205 & 0.198 & 0.215 & 0.208 & 0.194 & 0.217 & 0.201 \\
\hline Energy & 0.182 & $0.165^{* *}$ & 0.186 & 0.185 & 0.176 & 0.190 & 0.193 \\
\hline Environment & 0.164 & 0.159 & 0.168 & 0.157 & 0.160 & 0.158 & $0.183^{*}$ \\
\hline Immigration & 0.208 & 0.197 & 0.217 & 0.213 & 0.207 & 0.215 & 0.193 \\
\hline Regional & 0.211 & $0.234^{* *}$ & 0.198 & 0.219 & $0.227^{*}$ & 0.193 & $0.185^{*}$ \\
\hline $\begin{array}{l}\text { Unemployment/ } \\
\text { social policy }\end{array}$ & 0.194 & 0.191 & 0.193 & 0.185 & $0.209^{*}$ & 0.196 & 0.206 \\
\hline $\begin{array}{l}\text { Number of } \\
\text { observations }\end{array}$ & $\mathrm{N}=1581$ & $\mathrm{~N}=229$ & $\mathrm{~N}=209$ & $\mathrm{~N}=297$ & $\mathrm{~N}=299$ & $\mathrm{~N}=174$ & $\mathrm{~N}=125$ \\
\hline
\end{tabular}

Note: Entries are distance measures calculated following equation (1). ** significant at 5\%, * at 10\%. In keeping with the importance of the relative size of the distance measure, statistical significance is calculated comparing the distance measure in a given DG cluster (columns 2 to 7) relative to the distance measure calculated across all officials (column 1). For division of Directorate-Generals, see notes to tables 1 and 2. 